\title{
Pemasaran Politik Luar Negeri Sebagai Diplomasi Presiden Jokowi Untuk Menarik Investor Asing
}

\author{
Ahmad Baidawi \\ Dosen Ilmu Pemerintahan \\ Fakultas Ilmu Sosial dan Ilmu Politik \\ Universitas Jambi \\ ahmad.baidawi@unja.ac.id \\ A Zarkasi \\ Dosen Ilmu Hukum \\ Fakultas Hukum \\ Universitas Jambi \\ azarkasi riviksuryamulya@yahoo.com
}

\begin{abstract}
This paper wants to explain about Foreign Policy Marketing as President Jokowi's diplomacy to attract foreign investors. As we know, the Indonesian state from a geographical aspect has a very large area consisting of hundreds or even thousands of islands and straits. But the extent of the Indonesian territory has not been balanced with economic development such as infrastructure in all regions of Indonesia. This study aims to analyze the policies of President Jokowi in inviting foreign investors to invest directly in Indonesia and see the effect of foreign direct investment on foreign direct investment (FDI) on economic growth in Indonesia. The method used in this research is Qualitative Descriptive. The results or findings of this study indicate that the Marketing of Foreign Political Policy conducted by President Jokowi to attract foreign investors in Indonesia is through the economic Diplomacy Way and providing legal certainty for Foreign Investors investing in Indonesia and Foreign Investment can improve Infrastructure in Indonesia.
\end{abstract}

Keywords: Marketing, Foreign Policy, Diplomacy, Foreign Direct Investment.

\begin{abstract}
ABSTRAK
Tulisan ini ingin menjelaskan tentang Pemasaran Politik Luar Negeri sebagai diplomasi Presiden Jokowi untuk menarik investor asing. Seperti yang kita ketahui negara Indonesia dari aspek geografis memiliki wilayah yang sangat luas terdiri dari ratusan bahkan ribuan pulau dan selat. Namun luasnya wilayah indonesia tersebut belum seimbang dengan pembangunan ekonomi seperti infrastruktur di seluruh wilayah Indonesia. Penelitian ini bertujuan untuk menganalisis kebijakan Presiden Jokowi dalam mengajak para investor asing untuk berinvestasi langsung di Indonesia serta melihat pengaruh investasi asing langsung Foreign Direct Investment (FDI) pada pertumbuhan ekonomi di Indonesia. Metode yang dipakai dalam penelitian ini adalah Kualitatif Deskriptif. Adapun Hasil atau temuan dari penelitian ini menunjukkan bahwa Pemasaran Kebijakan Politik Luar Negeri yang dilakukan oleh Presiden Jokowi untuk menarik para investor asing di Indonesia adalah melalui Jalan Diplomasi Ekonomi dan memberikan kepastian hukum bagi para
\end{abstract}


Investor Asing yang berinvestasi di Indonesia dan Investasi Asing bisa meningkatkan Infrastruktur di Indonesia.

\section{Kata Kunci: Pemasaran, Politik Luar Negri, Diplomasi, FDI}

\section{Pendahuluan}

Kunjungan perdana Presiden Joko Widodo ke luar negeri setelah dilantik pada tahun 2014 merupakan deklarasi politik luar negeri indonesia dengan tafsir baru. Berpijak pada landasan politik bebas aktif, kebijakan luar negeri Indonesia bertumpu pada kepentingan nasional. Dengan kebijakan tersebut, publik meyakini kedaulatan negara dan perekonomian nasional tidak akan dirugikan.

Politik luar negeri pemerintahan Jokowi Widodo-Jusuf Kalla memakai slogan (seperti yang disampaikan oleh pakar hukum internasional dari UI, Hikmahanto Juwana), "Semua negara adalah sahabat sampai kedaulatan negara direndahkan dan kepentingan nasional dirugikan". Perwujudan tafsir baru atas kebijakan politik luar negeri ini tampak dalam gerak dan diplomasi Jokowi saat mengikuti Konferensi Tingkat Tinggi APEC, ASEAN, dan G-20 (Laksono, 2004). Geliat investasi harus dipelihara untuk menghadapi tantangan ekonomi yang semakin mengarah kepada liberalisasi ekonomi. Pada KTT APEC 2014 lalu, negara-negara anggota APEC telah menyapakati peta jalan perdagangan bebas Asia Pasifik. Selain itu, Indonesia juga harus menghadapi Masyarakat Ekonomi ASEAN (MEA) yang mulai berlaku akhir 2015. Selain Invetasi, juga diperlukan penegakan hukum untuk memberikan kepastian Investasi. Persoalan utama di Indonesia adalah kemiskinan dan pengangguran. Untuk mengatasi masalah itu, sangat diperlukan masuknya Investasi yang sangat besar sehingga bisa menciptakan lapangan pekerjaan.

Sejarah awal mengenai investasi Asing berawal dari sejarah perdagangan internasional yang muncul pasca perang dunia II sebagai produk dari persaingan ideologi liberal yang bersaing dengan merkantilisme. Awal tahun 1970-an, sistem perdagangan lebih banyak didominasi oleh gagasan liberal yang diajukan oleh Amerika. Kemudian pada periode pertengahan 1970-an sampai awal 1980-an, yaitu masa kritis Amerika, gagasan reformis 
52 | Ahmad Baidawi, A Zakarsi. Pemasaran Politik...

dan neomerkantilisme muncul mendominasi arena ekonomi politik internasional. Kemudian Pada pertengahan 1980-an sampai awal 1994 dimana perdagangan dunia giat kembali dan ideologi liberal berhasil muncul kembali membendung kecenderungan merkantilisme (Mohtar Mas'oed, 1994). Gagasan mengenai Liberalisasi ekonomi yang terbuka diperkenalkan oleh ahli ekonomi neoklasik David Ricardo dan adam smith dengan teori "keunggulan komparatif". Dilaksankannya prinsip keunggulan komparatif memastikan sebuah negara pada akhirnya akan meraih efisiensi ekonomi dan kesejahteraan yang lebih besar lewat partisipasi perdagangan luar negeri, bukannya lewat proteksi perdagangan. Penanaman Modal Asing langsung Foreign direct investment (FDI) merupakan salah satu bentuk investasi yang terjadi dizaman liberal ini.

Penanaman Modal Asing langsung Foreign direct investment (FDI) merupakan salah satu faktor utama pendorong perekonomian negara. Selain manfaat yang langsung dapat dirasakan seperti pembukaan lapangan kerja baru, transfer teknologi, peningkatan ekspor dan pendapatan pemerintah, FDI juga memberikan sinyal positif di lingkungan usaha yang akan memicu investor untuk berinvestasi lebih besar. Negara Indonesia memerlukan pendanaan dalam jumlah yang besar untuk menggerakkan roda perekonomian dalam negeri sehingga kesejahteraan penduduknya dapat meningkat dan kemiskinan dapat diturunkan. Baik sektor publik maupun swasta di Indonesia dituntut untuk menciptakan iklim investasi yang kondusif sehingga dapat bersaing dengan negara lain dalam menarik dana dari luar negeri. Dalam dekade terakhir ini Persoalan yang terjadi adalah para investor asing enggan menanamkan modalnya di negara Indonesia, sehingga diperlukan dibahas mengenai kebijakan apa yang harus disiapkan dan dikeluarkan oleh pemerintah Indonesia dalam mendatangkan investasi asing atau yang disebut Penanaman Modal Asing langsung Foreign Direct Investment (FDI).

Untuk menjamin para investor asing berinvestasi di Indonesia maka diperlukan suatu kebijakan dari pemerintah negara Indonesia. Dalam hal ini pemerintahan Presiden Jokowi-Jusuf kalla menggunakan politik luar negeri yang berangkat dari prinsip bebas aktif sebagai Diplomasi untuk menarik Para Investor Asing untuk berinvestasi di Indonesia dengan tujuan agar 
Perekonomian negara Indonesia bisa meningkat serta pembangunan disektor Infrastruktur di seluruh wilayah Indonesia bisa merata. Hal itu dapat dicapai dengan kebijakan dari pemerintahan Presiden Jokowi-Jusuf Kalla kepada para investor asing.

\section{Tinjauan Pustaka}

\section{a. Pemasaran Politik}

Menurut Adman Nursal (2004), pemasaran politik sebagai serangkaian aktivitas terencana, strategis tetapi juga taktis, berdimensi jangka panjang dan jangka pendek, untuk menyebarkan makna politik kepada para pemilih (Adman Nursal, 2004). Kemudian Newman dan Perloff (2004) mendefinisikan sebagai:

"...The application of marketing principle and procedure in poltical campaigns by various individuals and organizations. The procedures involved include the analysis, development, execution, ang manegement of strategic campaigns by candidates, political parties, governments, lobbyists and interest group that seek to drive public opinion, advance their own ideologies, win election, and pass legislation ang referenda in response to the need and wants of selected people ang groups in a society." (Penerapan prinsip dan cara kerja marketing di dalam kampanye politik oleh berbagai individu dan organisasi. Cara kerja itu sendiri meliputi analisis, perkembangan, pengeksekusian dan perencanaan strategi kampanye yang dilakukan oleh para kandidat, partai-partai politik, pemerintah, para penglobi dan kelompok kepentingan yang mencoba mengendalikan opini public, mengembangkan ideology mereka, memenangkan pemilihan dan melewati legislative dan pemungutan suara umum sebagai jawaban untuk keinginan dan keperluan dari kelompok dan orang-orang tertentu dalam masyarakat) (Newman \& Perloff, 2004).

Pengertian political marketing dengan essensi yang sama juga diungkapkan oleh Firmansyah yakni, penggunaan metode marketing dalam bidang politik (Firmanzah, 2007). Dari definisi-definisi di atas jelas menerangkan bahwa dalam pemasaran politik, yang ditekankan adalah penggunaan pendekatan dan metode marketing untuk membantu politikus atau para aktor politik (individual maupun partai) agar lebih efisien serta efektif dalam membangun hubungan dua arah dengan konstituen atau masyarakat. Konstituen atau masyarakat inilah yang pada akhirnya nanti akan menetukan kemenangan suatu partai politik dalam pemilihan umum. Semakin serunya persaingan antar partai politik yang satu dengan yang lain maka membuat semakin kreatif pula cara para partai politik ini untuk 
54 | Ahmad Baidawi, A Zakarsi. Pemasaran Politik...

mendapatkan perhatian masyarakat dan penerapan metode-metode marketing dalam politik saat ini adalah salah satu jawabannya.

\section{b. Politik Luar Negeri}

Menurut William D. Coplin dalam teori pengambilan keputusan dan kebijakan politik luar negeri ada tiga faktor yang mempengaruhi yaitu: kondisi politik dalam negeri, kemampuan ekonomi dan militer dan konteks internasional (William D. Coplin: 1992).

1. Situasi politik dalam negeri, bahwa politik dalam negeri hanyalah seperangkat determinan yang bekerja dalam politik luar negeri negara-negara. Walaupun keterbukaan suatu sistem politik atau tingkat stabilitas dalam negeri yang dialami oleh sistem itu, bisa membentuk aspek-aspek politik luar negeri tertentu, faktor-faktor lain juga bisa bekerja didalamnya, seperti faktor budaya yang mempengaruhi tingkah laku manusia.

2. Situasi ekonomi dan militer domestik, yakni suatu negara harus memiliki kemampuan dan kesediaan untuk menciptakan kemampuan yang diperlukan untuk menopang politik luar negerinya. Termasuk faktor geografis yang selalu mendasari pertimbangan pertahanan dan keamanan.

3. Konteks internasional, geografis, ekonomis dan politis merupakan tiga elemen penting dalam membahas dampak internasional terhadap politik luar negeri suatu Negara. Dalam lingkungan internasional setiap Negara memiliki lokasi atas daerah yang dikuasainya, dalam kaitannya dengan Negara-negara lain dalam sistem dan juga hubunganhubungan ekonomi dan politik Negara itu dengan Negara-negara yang lainnya.

\section{c. Diplomasi}

Diplomasi merupakan salah satu instrumen penting dalam pelaksanaan kepentingan nasional suatu negara. Diplomasi sebagai alat utama dalam pencapaian kepentingan nasional yang berkaitan dengan negara lain atau organisasi internasional. Melalui diplomasi ini sebuah negara dapat membangun citra tentang dirinya. Dalam hubungan antar negara, pada 
umumnya diplomasi dilakukan sejak tingkat paling awal sebuah negara hendak melakukan hubungan bilateral dengan negara lain hingga keduanya mengembangkan hubungan selanjutnya. Diplomasi merupakan praktek pelaksana perundingan antar negara melalui perwakilan resmi. Perwakilan resmi dipilih oleh negara itu sendiri tanpa ada campur tangan pihak lain atau negara lain. Diplomasi antar negara dapat mencakup seluruh proses hubungan luar negeri, baik merupakan pembentukan kebijakan luar negeri dan terkait pelaksanaannya.

Diplomasi juga diartikan sebagai suatu relasi atau hubungan, komunikasi dan keterkaitan. Selain itu diplomasi juga dikatakan sebagai proses interaktif dua arah antara dua negara yang dilakukan untuk mencapai poltik luar negeri masing-masing negara (S.L, Roy, 1995). Diplomasi dan politik luar negeri sering diibaratkan sebagai dua sisi mata uang yang tidak dapat dipisahkan. Dikatakan demikian karena politik luar negeri adalah isi pokok yang terkandung dalam mekanisme pelaksanaan dari kebijakan luar negeri yang dimiliki oleh suatu negara, sedangkan diplomasi adalah proses pelaksanaan dari politik luar negeri. Oleh karena itu baik diplomasi dan politik luar negeri saling berkaitan dan mendukung satu sama lain.

Diplomasi juga menjadi bagian yang sangat penting untuk dijadikan salah satu solusi atau jalan keluar untuk mengupayakan penyelesaian secara damai. Diplomasi dilakukan untuk mencapai suatu kepentingan nasional suatu negara. Meskipun diplomasi berhubungan dengan aktivitas-aktivitas yang damai, dapat juga terjadi di dalam kondisi perang atau konflik bersenjata karena tugas utama diplomasi tidak hanya manajemen konflik, tetapi juga manajemen perubahan dan pemeliharaannya dengan cara melakukan persuasi yang terus menerus di tengah-tengah perubahan yang tengah berlangsung (Watson Adam, 1984).

\section{d. Penanaman Modal Asing}

Penanaman Modal Asing (PMA) merupakan suatu bentuk investasi dengan jalan membangun, membeli total atau mengakuisisi perusahaan. Penanaman Modal di Indonesia ditetapkan melalui Undang-Undang No.25 tahun 2007 tentang Penanaman Modal Aing (PMA). Penanaman Modal Asing dalam Undang-Undang ini yaitu aktivitas menanamkan modal untuk 
56 | Ahmad Baidawi, A Zakarsi. Pemasaran Politik...

melakukan usaha di wilayah Republik Indonesia yang dilakukan oleh penanam modal asing, baik menggunakan modal asing seutuhnya ataupun yang bekerjasama dengan penanam modal dalam negeri (Pasal 1 Undang-Undang No. 25 tahun 2007 tentang Penanaman Modal). Pengertian modal asing dalam undang-undang tersebut yaitu sebagai berikut (Jufrida,Firdaus,dkk.2016):

1. Alat pembayaran luar negeri yang bukan merupakan bagian dari kekayaan devisa Indonesia, yang mendapat persetujuan pemerintah digunakan untuk pembiayaan perusahaan di Indonesia.

2. Alat-alat untuk perusahaan, termasuk penemuan-penemuan baru dari orang asing dan bahan-bahan, yang dimasukkan dari luar ke dalam wilayah Indonesia, selama alat-alat tersebut tidak dibiayai dari kekayaan devisa Indonesia.

3. Bagian dari hasil perusahaan yang berdasarkan undang-undang ini keuntungan yang diperkenankan ditransfer, tetapi dipergunakan untuk membiayai perusahaan di Indonesia.

\section{Metode Penelitian}

Metode penelitian yang akan digunakan dalam penelitian ini adalah Kualitatif. yang merupakan pendekatan yang memberikan kesempatan kepada peneliti untuk dapat melakukan deskripsi dan interpretasi secara terperinci untuk mendapatkan holistik pemahaman (W.H. Jati, 2013). Jenis penelitian ini dimaksudkan untuk memberikan gambaran mengenai masalah yang diteliti yaitu menjelaskan seperti apa kebijakan atau diplomasi yang telah dikeluarkan oleh Presiden Jokowi dalam menarik investor asing serta melihat bagaimana pengaruh investasi Asing bagi negara Indonesia. Metode pengumpulan data adalah penelitian kepustakaan yang didukung oleh media cetak seperti buku, majalah, koran, jurnal, dan juga media elektronik, terutama internet di mana data merupakan sumber sekunder. Data-data ini akan dianalisis dalam kerangka teori yang telah ditentukan untuk membuktikan bahwa hipotesis itu akurat dan akhirnya dapat menjawab pertanyaan penelitian. Untuk mensistematisasikan data yang dikumpulkan, analisis ini dilakukan melalui beberapa tahapan, yaitu: reduksi data, pemaparan data, deskripsi dan verifikasi serta menarik kesimpulan. 


\section{Pembahasan}

\section{a. Pemasaran Politik Luar Negeri}

Menurut Adman Nursal (2004), pemasaran politik sebagai serangkaian aktivitas terencana, strategis tetapi juga taktis, berdimensi jangka panjang dan jangka pendek, untuk menyebarkan makna politik kepada para pemilih, pengikut dan lawan politik. Sedangkan Politik Luar Negeri adalah suatu kebijakan yang diambil oleh pemerintah suatu negara atau komunitas politik lainnya dalam hubungan dengan negara dan aktor bukan negara di dunia internasional (Abu bakar, 2010). Politik luar negeri juga menjembatani batas wilayah dalam negeri dan lingkungan internasional. Politik luar negeri bisa berupa hubungan diplomatik, mengeluarkan doktrin, membuat aliansi, mencanangkan tujuan jangka panjang maupun jangka pendek.

Dalam kontek ini pemasaran politik luar negeri sebagai diplomasi Presiden Jokowi adalah Suatu strategi, aktivitas untuk memasarkan dan menyebarkan politik luar negeri oleh pemerintahan Presiden Jokowi kepada negara-negara luar dengan tujuan negara luar bisa memahami politik luar negeri Indonesia, bisa bekerjasama dalam bidang politik, ekonomi, sosial dan budaya dengan tetap mengedepankan kepentingan nasional. Selain itu, dalam politik luar negeri, Indonesia memiliki tujuan yaitu mempertahankan kemerdekaan bangsa dan menjaga keselamatan bangsa, memperoleh dari luar negeri barang-barang yang diperlukan untuk memperbesar kemakmuran rakyat, perdamaian internasional, dan persaudaraan segala bangsa sebagai pelaksanaan cita-cita yang tersimpul dalam Pancasila (Hatta, 1953).

Sebagai contoh, Pada tanggal 16/11/14 dihari itu merupakan hari terakhir dari kunjungan perdana Presiden Jokowi dalam kancah Internasional, untuk mengikuti rangkaian KTT APEC, ASEAN, dan G20. Dalam kesempatan itu. Dengan tanpa basa basi, jokowi langsung meminta negara dengan ekonomi terbesar di dunia untuk berpartisipasi dalam pembangunan infrastruktur pelabuhan, rel kereta api, jalan tol, dan pembangkit listrik di Indonesia. Jokowi juga minta agar Asian Infrastructure Investmen Bank yang 50 persen sahamnya dimiliki Tiongkok dan beranggotakan 20 negara dapat berkantor pusat di Indonesia. Hari berikutnya, Jokowi berbicara dihadapan 500 pemimpin perusahaan terkemuka, forum APEC CEO Summit. Di forum itu, Jokowi mempresentasikan peluang Investasi pembangunan Infrastruktur 
58 | Ahmad Baidawi, A Zakarsi. Pemasaran Politik...

di Tanah Air (Kompas, 2014). Hal ini merupakan salah satu contoh dari pemasaran politik luar negeri yang dijalankan oleh Presiden Jokowi untuk menarik para investor asing untuk berinvestasi di Indonesia.

Politik luar negeri Indonesia memiliki landasan yang membaginya ke dalam tiga kategori, yaitu landasan idiil, landasan konstitutsional, dan landasan operasional. Landasan idiil politik luar negeri Indonesia, yaitu Pancasila. Pancasila dikenal sebagai dasar negara bangsa Indonesia yang terdiri dari lima sila. Kelima sila tersebut menjelaskan mengenai pedoman dasar bagi pelaksanaan kehidupan berbangsa dan bernegara yang ideal dan mencakup seluruh sendi kehidupan manusia (Alami, 2008:28).

Landasan konstitusional politik luar negeri Indonesia, yaitu UndangUndang Dasar 1945. Dalam UUD 1945 ini mengundang pasal-pasal yang mengatur kehidupan berbangsa dan bernegara, serta menjelaskan mengenai garis-garis besar dalam kebijakan luar negeri Indonesia. Hal ini berfungsi sebagai pedoman pelaksanaan untuk mencapai kepentingan nasional Indonesia (Alami, 2008:28). Sedangkan, landasan operasionalnya, yaitu bebas aktif. Pelaksanaan landasan operasional ini mengalami perubahan karena menyesuaikan dengan kepentingan nasional. Selain itu, landasan operasional juga mengalami perluasan makna karena politik luar negeri Indonesia yang mengalami perkembangan selama enam dekade (Alami, 2008:28-29).

Landasan operasional politik luar negeri Indonesia mengalami perubahan dan dapat dilihat dengan adanya perbedaan dalam memahami landasan operasional pada setiap masanya, misalnya pada masa Orde Lama dan Orde Baru. Pertama, masa Orde Lama dijelaskan bahwa landasan operasional politik luar negeri Indonesia adalah bebas aktif. Hal ini dapat dilihat dalam maklumat dan pidato-pidato Presiden Soekarno. Selain itu, pada dasawarsa 1950-an menjelaskan bahwa landasan operasional mengalami perluasan makna. Perluasan makna tersebut diyatakan oleh Presiden Soekarno dalam pidatonya yang berjudul "Jalannya Revolusi", maksud dalam pidato tersebut, yaitu mengenai prinsip bebas aktif yang dicerminkan dengan adanya hubungan ekonomi dengan luar negeri. Sedangkan, masa Orde Baru dijelaskan bahwa landasan operasional politik luar negeri Indonesia semakin dipertegas dengan adanya peraturan formal. Penegasan yang diwujudkan 
melalui Ketetapan MPRS No. XII/MPRS/1965 tanggal 5 Juli 1966, Ketetapan MPR tanggal 22 Maret 1973, petunjuk Presiden 11 April 1973, petunjuk bulanan Presiden sebagai Presiden sebagai ketua Dewan Stabilisasi Politik dan Keamanan, dan keputusan-keputusan Menteri Luar Negeri, serta dalam TAP MPR tentang Garis-Garis Besar Haluan Negara (GBHN). Selain itu, landasan operasional pasca Orde Baru dijelaskan bahwa mengalami perubahan pemerintahan secara cepat. Hal ini dapat dilihat dengan adanya dua kabinet yang memerintah pada masa pemerintahan pasca Orde Baru, yaitu Kabinet Gotong Royong dan Kabinet Indonesia Bersatu (Alami, 2008:28-34).

Pada masa pemerintahannya, Kabinet Gotong Royong (2001-2004) mengoperasionalkan politik luar negeri Indonesia melalui Ketetapan MPR No.IV/MPR/1999 tanggal 19 Oktober 1999 tentang GBHN dalam rangka mewujudkan tujuan nasional periode 1999-2004, UU No.37 tahun 1999 tentang Hubungan Luar Negeri, UU No. 24 tahun 2000 tentang Perjanjian Internasional, dan Perubahan UUD 1945. Latar belakang ketetapan MPR No. IV/MPR/1999 adalah krisis ekonomi dan krisis nasional pada tahun 1997. Dalam UU No. 37 tahun 1999 menekankan pada aspek penyelenggaraan hubungan luar negeri dan politik luar negeri. Hal ini dapat dilihat dalam politik luar negeri bebas aktif untuk kepentingan nasional, mengatur keterlibatan pihak-pihak dalam lembaga negara dan lembaga pemerintah dalam penyelenggaraan hubungan luar negeri dan pelaksanaan politik luar negeri. Sementara itu, UU No. 24 tahun 2000 menekankan pada pentingnya menciptakan suatu kepastian hukum dalam perjanjian internasional (Alami, 2008:34-37).

Pada masa pemerintahan Kabinet Indonesia Bersatu (2004-2009) politik luar negeri dioperasikan ke dalam tiga program utama, yaitu pemantapan politik luar negeri dan optimalisasi diplomasi Indonesia dalam penyelenggaraan hubungan luar negeri dan pelaksanaan hubungan luar negeri, peningkatan kerjasama internasional yang bertujuan memanfa atkan secara optimal berbagai peluang dalam diplomasi dan kerjasama internasional, dan penegasan komitmen perdamaian dunia yang dilakukan dalam rangka membangun dan mengembangkan semangat multilateralisme dalam memecahkan berbagai persoalan keamanan internasional (Alami, 2008:34-40).Dalam hal ini Indonesia melakukan diplomasi sebagai upaya 
60 | Ahmad Baidawi, A Zakarsi. Pemasaran Politik...

mendapatkan pengakuan secara internasional. Namun dalam pelaksanaannya, upaya tersebut tidak mudah bagi Indonesia. Selain jalur diplomasi yang ditempuh, Indonesia harus melalui perjuangan fisik bersenjata. Bukan hanya itu saja yang menyebabkan Indonesia merasa sulit dalam mendapatkan pengakuan internasional. Hal ini juga diakibatkan dari adanya perkembangan politik internasional yang pada saat itu sedang tidak mendukung. Politik internasional pada masa itu mengalami persaingan tajam yang terjadi antara blok barat dengan blok timur. Persaingan yang terjadi ini kemudian mempersulit posisi Indonesia dalam berpihak. Namun, sebagai jawabannya Indonesia tidak memilih salah satu dari kedua blok tersebut (Alami, 2008:40-41).

Indonesia tidak memilih di antara kedua blok tersebut menjadi prinsip dan pilihan dalam politik luar negeri Indonesia yang disebut politik bebas dan aktif. Bebas dalam artian ini adalah tidak berpihak pada blok-blok yang ada dengan bersikap netral dan memiliki cara tersendiri dalam mengatasi persoalan internasional. Namun demikian, dalam hal ini Indonesia tidak dapat dikatakan sebagai negara yang netral posisinya. Sikap netral yang dimaksud di sini adalah sikap netral yang anti sosial, namun sikap ini tidak sesuai dengan yang dilakukan Indonesia karena Indonesia menjadi anggota PBB (Hatta, 1953:12). Hal ini kemudian ditegaskan oleh Hatta karena Indonesia tidak dihadapkan pada suatu pilihan dalam hubungan negara-negara yang sedang berperang, melainkan Indonesia mengambil sikap tersebut untuk memperkokoh dan memperjuangkan perdamaian (Alami, 2008:43-44). Sementara itu, aktif dalam artiannya menjelaskan mengenai adanya partisipasi Indonesia dalam menjaga perdamaian dan meredakan ketegangan yang terjadi diantara kedua blok tersebut. Politik luar negeri Indonesia yang berdasarkan prinsip bebas aktif ini juga tercantum dalam Pembukaan Undang-Undang Dasar 1945 alinea keempat. Dalam alinea tersebut dijelaskan bahwa Indonesia menentang segala bentuk penjajahan dan ikut serta melaksanakan ketertiban dunia (Alami, 2008:44-45).

\section{b. Diplomasi Jokowi dan Kebijakan Menarik Investor Asing}

Berdasarkan Nawa Cita Presiden Joko Widodo dan RPJMN Bappenas, Kementerian Luar Negeri RI di bawah kepemimpinan Menteri Luar Negeri (Menlu) Retno Marsudi merumuskan Rencana Strategis (Renstra) Kemlu 
2015-2019. Renstra tersebut memiliki slogan "Diplomasi untuk rakyat" dan visi "Terwujudnya wibawa diplomasi guna memperkuat jati diri bangsa sebagai negara maritim untuk kepentingan rakyat". Secara singkat, Renstra Kemlu 2015-2019 menjabarkan tiga misi, tiga tujuan, dan delapan sasaran strategis. Tiga misi Kemlu tersebut adalah: Pertama, Memperkuat kepemimpinan Indonesia sebagai negara maritim dalam panggung internasional. Kedua, Perwakilan RI yang berkualitas. Ketiga, Memantapkan Kemlu sebagai pelaksana hubungan luar negeri.

Sementara itu, tiga tujuan Kemlu yang dinyatakan dalam Renstra adalah: Pertama, Kepemimpinan Indonesia dalam kerja sama internasional. Kedua, Nilai manfaat ekonomi yang optimal. Ketiga, Menguatnya kapasitas SDM Kemlu yang berkualitas. Sedangkan, delapan sasaran strategis Kemlu meliputi: 1. Diplomasi maritim dan perbatasan yang kuat, 2. Kepemimpinan Indonesia di ASEAN yang meningkat, 3. Peran Indonesia di dunia internasional yang meningkat, 4. Diplomasi ekonomi yang kuat, 5. Pelayanan dan perlindungan Warga Negara Indonesia (WNI) dan Badan Hukum Indonesia (BHI) dan diaspora yang prima, 6. Kebijakan luar negeri yang berkualitas, 7. Dukungan dan komitmen yang tinggi atas kebijakan luar negeri Indonesia, 8. Meningkatkan kapasitas organisasi dengan kompetensi SDM Kemlu berbasis teknologi.

Berdasarkan Renstra, delapan sasaran strategis ini ditargetkan untuk selesai dalam lima tahun masa pemerintahan Joko Widodo. Namun, perlu diingat bahwa untuk mencapai target capaian kebijakan luar negeri Indonesia yang telah ditetapkan RPJMN dan Renstra tidaklah mudah. Ada banyak faktorfaktor baik domestik maupun internasional yang mempengaruhi kinerja dan efektifitas Kemlu.

\section{Diplomasi Ekonomi}

Mendirikan sistem ekonomi yang kuat adalah salah satu dari Nawa Cita Presiden Joko Widodo dan Kemlu di sektor ini juga memiliki peran yang sangat penting dalam mendorong pertumbuhan ekonomi nasional melalui 
$62 \mid$ Ahmad Baidawi, A Zakarsi. Pemasaran Politik...

fasilitasi peningkatan perdagangan serta investasi internasional. Fokus pada Kemlu adalah mendorong diplomasi ekonomi dalam sektor perdagangan, pariwisata, investasi, dan kerja sama ekonomi.

Pada dasarnya, kendala dalam melakukan diplomasi ekonomi, khususnya dalam hal promosi perdagangan, pariwisata dan investasi, adalah sinergi dengan kementerian atau lembagaterkait kebijakan ekonomi dalam negeri (Kemenlu: 2015). Selain itu, masalah regulasi perizinan dan ketenagakerjaan membuat Indonesia kurang dapat bersaing, terutama di antara negara-negara di kawasan ASEAN. Jika menyangkut masalah ekonomi, perlu diakui bahwa sinergi antara kementerian atau lembaga terkait dengan Kemlu sangat penting karena cakupan dari sektor ekonomi sangat luas. Kemlu dalam konteks ini hanya menjalankan fungsi hubungan luar negeri sesuai dengan undang-undang No. 37 tahun 1999. Namun masalah ini dapat diatasi karena Kemlu sudah membentuk Pokja Diplomasi Ekonomi yang melibatkan seluruh pemangku kepentingan di bidang ekonomi, termasuk kementerian, lembaga serta perwakilan Indonesia di luar negeri demi peningkatan kerja sama di bidang perdagangan, investasi dan pariwisata dengan negara-negara sahabat.

Selama tahun 2015, diplomasi ekonomi Indonesia berhasil mencapai nilai realisasi sebesar 98,32\% dari target sebesar 79\%. Pada tahun ini, Indonesia juga berhasil menuntaskan naskah kesepakatan di bidang ekonomi, keuangan, dan pembangunan baik di level bilateral, regional, maupun internasional sebanyak 66, melampaui target yang ditentukan yaitu sebesar 48 (Kemenlu: 2015). Beberapa sorotan dari tahun ini yaitu perjanjian dagang dengan Jepang yaitu MoU antara BKPM Indonesia dengan Japan External Trade Organization (JETRO). Selain pertemuan antarpemerintah (government to government), kesepakatan bisnis antara pengusaha swasta juga menunjukkan jumlah yang cukup besar. Sebagai contoh, perusahaan Indonesia Lion Air menandatangani MoU dengan perusahaan Inggris Rolls Royce senilai USD 140 Juta untuk Lion Air membeli mesin pesawat terbang Trent 700 (Kemenlu: 2015).

Selain itu, perlu diingat juga bahwa Indonesia juga berperan aktif dalam berbagai forum ekonomi dan pembangunan di level intra-kawasan, antar-kawasan, dan multilateral, antara lain dalam perkumpulan dua puluh 
perekonomian terbesar dunia (G20), Asia-Pacific Economic Cooperation (APEC) dan ASEM. Forum-forum ekonomi internasional sangat penting bagi Indonesia untuk memajukan agenda nasional melalui rekomendasi dalam isu tertentu. Data pada tahun 2015 menunjukkan sebanyak 59 rekomendasi Indonesia di bidang ekonomi dan pembangunan yang diterima dari jumlah yang sama yang ditawarkan, dengan kata lain terdapat $100 \%$ realisasi yang tercapai (Kemenlu: 2015). Ini menunjukkan bahwa Indonesia telah sukses menyuarakan kepentingan nasional dalam forum-forum ekonomi dunia.

Dari tingkat promosi Trade, Tourism, Investment, and Services (TTIS), menunjukkan paling tidak ada 37 pertemuan dan perundingan untuk meningkatkan investasi, ekspor, dan promosi pariwisata, antara lain membahas tentang Indonesia-Japan Economic Partnership Agreement (IJEPA), ASEAN-Japan Comprehensive Economic Partnership (AJCEP), ASEANHongKong Free Trade Agreement (AHKFTA), ASEAN-Korea Free Trade Agreement (AKFTA), dan Regional Comprehensive Economic Partnership (RCEP). Untuk meningkatkan pariwisata, Kemlu telah memberikan fasilitas berupa fasilitas bebas visa kunjungan singkat untuk 75 negara. Jumlah promosi TTIS sepanjang 2015 mencapai 69 kali, yang melebihi target yang ditetapkan sebanyak 65 kali (Kemenlu: 2015). Beberapa partisipasi Kemlu dalam promosi pariwisata adalah dalam Pameran Gateway Show dan Sales Mission di Afrika Selatan dan China-ASEAN Expo (CAEXPO) di Nanning, Tiongkok.

Selama 2016, sebanyak 194 perjanjian ekonomi bilateral dan multilateral yang didorong oleh diplomat RI telah disepakati, mereka juga memfasilitasi partisipasi 125 negara dalam trade expo Indonesia yang membukukan transaksi sebesar USD 974,76 Juta pada tahun itu. 48 Selain itu, Kemlu juga berhasil memfasilitasi penandatanganan 31 kontrak dagang senilai sebesar USD 200 Juta (Kemenlu: 2016). Pencapaian diplomasi Indonesia telah berhasil mendorong produk karya anak bangsa seperti PT. Inka berhasil untuk mengekspor 150 gerbong kereta senilai USD 72,3 Juta, membantu PT DI mengekspor pesawat CN 235 ke Senegal dan Thailand, serta membangun pabrik mie instan Indonesia di Serbia senilai $€ 11$ juta untuk memenuhi permintaan pasar Eropa. 
64 | Ahmad Baidawi, A Zakarsi. Pemasaran Politik...

Pada tahun 2017, indeks diplomasi ekonomi Indonesia secara keseluruhan mampu mencapai realisasi sebesar $141,75 \%$ yang merupakan peningkatan dari tahun sebelumnya (Kemenlu: 2017). Spesifik di bidang kesepakatan ekonomi menunjukkan perkembangan yang sangat baik, dari target Kemlu di tahun 2017 yang adalah 46 kesepakatan, realisasinya mencapai 113 kesepakatan (atau 245,65\% dari target) yang mencakup, antara lain, kontribusi pendanaan untuk pembangunan, kerja sama ekonomi dan teknik (dengan Arab Saudi), kerja sama ekonomi dan teknik (dengan Turki dan Angola), pertanian (dengan Filipina), serta pembebasan visa, ekonomi sirkuler, manajemen limbah dan air (dengan Denmark). Meskipun terdapat pencapaian yang cukup baik, masih terdapat kendala, antara lain mengenai komitmen dan koordinasi antar pemangku kepentingan di Indonesia yang kurang responsif dalam penanganan isu terkait bidang ekonomi, sosial dan budaya sehingga membuat sulitnya koordinasi kegiatan dan tindak lanjut dokumen kesepakatan. Selain itu, dinamika politik, ekonomi dan sosial negara mitra juga menjadi alasan terhambatnya penyelesaian dokumen perjanjian kerja sama.

Mengenai rekomendasi Indonesia di bidang ekonomi yang diterima di forum internasional, performa Kemlu di tahun 2017 mencapai realisasi sebesar 95,88\% (yakni dari 364 rekomendasi yang diberikan, 349 rekomendasi diterima) yang melebihi target $89 \% .56$ Tahun ini beberapa prakarsa/rekomendasi yang diberikan Indonesia diterima dalam pertemuan tingkat tinggi. Misalnya pertemuan G20 di Hamburg, Jerman, mengapresiasi aplikasi keanggotaan Indonesia pada Financial Task Force (FATF) dan pertemuan APEC Economic Leaders Week di Vietnam, menerima rekomendasi Indonesia mengenai Free Trade Area of the Asia-Pacific (FTAAP), pembangunan konektivitas daerah terpencil, pemberdayaan petani dan nelayan, internasionalisasi UMK, serta pembangunan sumber daya manusia di era digital.

Mengenai promosi perdagangan, pariwisata dan investasi yang dilakukan Kemlu pada tahun 2017 tercatat terdapat 99 kali promosi yang jumlahnya 111,24\% lebih besar dari target 89 kali (Kemenlu: 2017). Promosi perdagangan, pariwisata dan investasi dilakukan di negara mitra untuk mendorong peningkatan perdagangan, investasi dan wisatawan asing, juga di 
Indonesia untuk mempromosikan akses dan peluang pasar di negara mitra, misalnya dengan pameran pariwisata di Zagreb, Kroasia dan sosialisasi buku "Panduan Berbisnis dengan Pihak Iran" di Jakarta. Menlu dan delegasi Indonesia ke beberapa negara untuk melakukan promosi, antara lain ke Nigeria, Ethiopia, dan Rusia. Selain itu Indonesia juga melakukan diplomasi perdagangan dengan negara-negara Timur Tengah dengan mengadakan Indonesia-Middle East Annual Gathering on Economy di Bandung.

2. Kebijakan Untuk Menarik Investor Asing

Ada beberapa pilihan kebijakan yang dapat dilakukan oleh pemerintah kita pada saat ini untuk menarik Investor Asing dalam Pembangunan Infrastruktur di Indonesia yaitu: Pertama, Hadirnya peran negara (state). Hakikat kebijakan ekonomi adalah intervensi negara secara cermat dan tersedianya mekanisme sehingga mendorong pertumbuhan dan investasi yang cepat. Dalam artian diperlukan kapabilitas negara melakukan intervensi secara efektif melalui instrumen kebijakan untuk mendukung pembagunan ekonomi (Winarno: 2002). Penanaman modal asing ataupun modal dalam negeri tidak dibiarkan lepas begitu saja tanpa adanya intervensi dari negara bersama dengan perusahaan dalam menentukan arah kebijakan dan pasar konsumen yang dituju. Contoh kasus pada korea selatan yang keuntungannya diperoleh oleh negara dan juga dinikmati oleh masyarakat dan FDI melalui pertumbuhan ekonomi yang cukup fantastis. Lemahnya peran FDI dan perusahaan-perusahaan multinasional di Korea Selatan banyak dipengaruhi oleh semangat nasionalisme dinegara tersebut. Bahkan hongkong yang hampir sama sekali menyandarkan diri pada pasar bebas pun, dalam kenyataanya negara tetap memegang posisi penting keuntungannya yang ditunjukan oleh pemerintah hongkong melalui belanja progresif pemerintah.

Kedua, mensinergikan peran dari rakyat, industri atau perusahaan lokal, penanam modal asing dan negara. Dengan cara meberdayakan masyarakat dengan industri komoditi dibidang pertanian dan perkebunan dengan cara penyuluhan cara bertanam yang baik untuk memperoleh bibit unggul dibidang-bidang tersebut, kemudian negara menghargai masyarakat tadi dengan pemberian insentif ataupun upah terhadap pekerjaannnya, disamping negara dan perusahaan lokal mencari penanam modal asing untuk menanamkan modalnya terhadap hasil pertanian, perdagangan, dan 
66 | Ahmad Baidawi, A Zakarsi. Pemasaran Politik...

perkebunan. Dan juga melalui bantuan networking dari negara. Keuntungan hasil yang diperoleh akan terbagi tapi cenderung akan lebih menguntungkan negara dan masyarakat pada daerah tersebut. Namun diperlukan perbaikan iklim yang kondusif terhadap investasi asing dalam negara merupakan faktor yang sangat mendukung.

Ketiga, berkaca pada keberhasilan ekonomi negara singapura dimana antara tahun 1960-1999, pertumbuhan riil mencapai $8 \%$. Ada tiga hal yang menentukan keberhasilan ekonomi negara singapura, yaitu: pertama, pengadopsian pendekatan ekonomi terbuka dengan mendorong FDI mendukung rezim perdagangan bebas, dan mempromosikan industri berorientasi ekspor. Kedua, menciptakan lingkungan yang kondusif untuk pertumbuhan perusahaan-perusahaan swasta dengan mempertahankan kebijakan ekonomi makro yang stabil, menjaga pemerintahan yang bersih dan jujur yang menyediakan jasa yang efisien dan mempertahankan transparansi, kerangka aturan yang probisnis, mempertahankan harmoni industri buruh melalui kerjasama anatar negara, gerakan buruh dan pemimpin-pemimpin industri. Ketiga, berinvestasi dengan gencar disektor infrastruktur publik dan pengembangan sumber daya manusia dan memastikan pencapaian standar kualitas yang tinggi di kedua bidang (Yuniarti: 2007).

Indonesia hanya berada pada posisi 135 sebagai negara yang menjadi tujuan investor dunia dari 175 negara yang disurvei. Hal itu disebabkan karena ketidak tegasan pemerintah dalam menentukan arah investasi perdagangan di Indonesia seperti sekarang ini. Sistem yang sangat liberal ternyata tidak juga mendatangkan investasi asing yang besar. Kebijakan penanaman modal asing yang sangat liberal ini cenderung menyerahkan semua kepada pasar sehingga apabila terjadi persaingan akibat dari globalisasi misalnya perusahaan modal asing yang telah mengadakan kontrak kerjasama dengan pihak Indonesia mendapat saingan yang kuat dari perusahaan lain untuk mencapai penjualan terhadap konsumen dipasar global tentu akan membutuhkan bantuan dari pemerintah dalam menjalin networking dengan konsumen dinegara lain jadi tidak bisa dibiarkan begitu saja tanpa koridor yang jelas. Singkatnya sistem investasi dan perdagangan indonesia yang sangat liberal tidak bisa menjamin penanaman modal asing di 
indonesia akan merasa aman menanamkan modalnya. Selain itu berdasarkan data mengenai perlidungan bisnis di Indonesia yang dikeluarkan dari World Economic Forum (2007) yang berpusat di Geneva (Swiss) untuk The Global Competitiveness Report 2007-2008 menunjukkan bahwa dari 131 negara yang masuk dalam sampel penelitiannya, Indonesia berada pada peringkat ke 93 untuk pertanyaan apakah pengusaha (responden) bisa mengandalkan pelayanan dari polisi untuk melindungi usahanya dari kriminalitas (Tulus Tambunan: 2007). (Lihat Table dibawah in

The Global Competitiveness Report 2007-2008

\begin{tabular}{|c|c|}
\hline Peringkat & Negara \\
\hline 1 & Finlandia \\
\hline 2 & Denmark \\
\hline 3 & Jerman \\
\hline 4 & Singapura \\
\hline 93 & Indonesia \\
\hline 131 & Venezuela \\
\hline
\end{tabular}

Kepastian Hukum dan Kebijakan Insentif

Selain faktor diatas, ada faktor lain yang terpenting dalam upaya menarik investor asing ke Indonesia yaitu adanya jaminan kepastian hukum dalam menjalankan usaha. Pengalaman selama masa orde Baru, Pemerintah kurang berhasil dalam memberikan jaminan bahwa peraturan yang telah ditetapkan dalam kegiatan investasi dan usaha akan tetap dipegang walaupun sistem pemerintahan berubah. Adapun Jaminan kepastian hukum ini sangat dibutuhkan bagi para investor maupun calon investor dalam kegiatan investasi jangka panjang. Hal ini dapat kita lihat dalam kegiatan investasi di beberapa bidang seperti, bidang eksplorasi minyak bumi dan hasil tambang, industri berat, perkebunan, kawasan industri, apartemen dan gedung bertingkat. 
68 | Ahmad Baidawi, A Zakarsi. Pemasaran Politik...

Cukup menarik untuk diamati kecenderungan lembaga internasional seperti IMF yang baru-baru ini mengkhawatirkan perubahan-perubahan yang akan terjadi dalam iklim berinvestasi, khususnya dengan adanya otonomi dan kegiatan desentralisasi pembangunan. Kekhawatiran itu tentunya tidak beralasan mengingat dengan adanya UU No.22 Tahun 1999, khususnya pasalpasal dalam bidang pengawasan (pasal 114) dan bidang peraturan daerah (pasal 70), telah membatasi kemungkinan ruang gerak yang semena-mena yang akan dilakukan oleh manajemen pemerintahan daerah. Dengan adanya sistem perencanaan dan sistem prosedur yang transparan, baku dan disetujui oleh DPRD maka diharapkan calon investor dapat lebih mendapatkan kepastian dalam berusaha.

Melihat pada kepentingan perusahaan asing di masa mendatang dalam melakukan kegiatan investasi di daerah, Pemerintah Pusat dan DPR-Pusat harus segera mengeluarkan ketentuan perundang-undangan tentang penanaman modal, pertanahan dan pemanfaatan lahan melalui zoning, sistem perencanaan dan perizinan yang keseluruhannya dengan ketentuanketentuan dalam UU No 22 Tahun 1999 dan UU No 25 tahun 1999 dalam rangka otonomi daerah. Produk-produk hukum tersebut hendaknya juga memberikan kepastian pada para investor bahwa modal yang ditanamkannnya dalam bentuk investasi langsung tidak akan dinasionalisasikan oleh Pemerintahan Daerah, termasuk bahwa mereka masih bebas sewaktu-waktu untuk melakukan tindakan "exit dari industri" dan mentransfer laba usaha ke luar negeri.

Sangat diharpakan jika undang-undang tersebut memberikan juga hak kepada para investor asing untuk mengajukan keberatan-keberatan kepada Pemerintah Pusat atas produk hukum di daerah yang merugikan. Akhirnya, segala Peraturan Daerah yang akan dikeluarkan tidak boleh bertolak belakang dengan produk hukum yang telah ditetapkan kepada mereka sebelum dikeluarkannya kedua Undang-undang tentang otonomi dan desentralisasi.

Proses desentralisasi pembangunan akan membawa konsekuensi pada kemungkinan masing-masing daerah untuk berlomba-lomba memberikan sistem perangsang maupun insentif investasi yang terbaik. Satu hal yang perlu diperhatikan adalah implikasi kebijaksanaan insentif investasi di daerah pada skala nasional secara "zero sum", seperti halnya pemberian tax holiday 
oleh masing-masing daerah. Untuk mengatasi masalah diatas hendaknya ketentuan-ketentuan kebijakan insentif investasi yang dapat merugikan kepentingan perekonomian secara nasional tidak diberikan kewenangannya kepada daerah. Adapun sistem pemberian insentif investasi di daerah hendaknya dikaitkan dengan visi dan tujuan yang tercantum dalam master plan perekonomian daerah; mempertimbangkan berbagai motive yang mendorong perusahaan asing untuk berusaha dan dampak kebijaksanaan bagi para pelaku bisnis dan calon investor di sektor ekonomi lainnya.

\section{Pengaruh Investasi Asing Terhadap Ekonomi Indonesia}

Ngara Indonesia terus berupaya dalam pembangunan ekonomi guna meningkatkan kemajuan perekonomian negara. Beberapa upaya telah dilakukan oleh pemerintah, salah satunya adalah dengan menggencarkan investasi atau mengajak masyarakat untuk giat menghimpun dana di pasar modal. Selain itu, kehadiran para investor asing di Indonesia juga dilandasi oleh UU RI No. 25 Tahun 2007 tentang Penanaman Modal. Berdasarkan undang-undang tersebut maka Negara Indonesia memberikan kebebasan kepada investor domestik maupun investor asing untuk menanamkan modalnya dalam melakukan kegiatan usahanya di wilayah Indonesia. Sehingga jelas perusahaan Indonesia diperbolehkan untuk melakukan kerjasama dengan pihak asing dalam mempertahankan eksistensinya dalam dunia bisnis. Semakin banyak investor asing yang menanamkan modalnya di indonesia, itu berarti dalam sektor industri mengalami pertumbuhan. Sehingga semakin luas kesempatan kerja bagi masyarakat Indonesia, serta Indonesia sedikit demi sedkit mampu mengurangi ketergantungannya terhadap negara lain. Dari segi pemenuhan kebutuhan yang dibutuhkan.

Pemerintah indonesia sepakat mengeluarkan surat berharga berupa obligasi maupun saham dengan tujuan untuk memanbah pendapatan negara serta menutupi defisit yang dialami oleh APBN Indonesia. Peranan obligasi yaitu memberikan sumbangsih dalam penambahan modal untuk kegiatan pembangunan yang membutuhkan dana tidak sedikit. Di samping itu Indonesia mendapatkan tambahan pemasukan dari segi pajak, apabila pada saat Indonesia membayar bunga obligasi pada negara yang bersangkutan. Di sisi lain pemerintah Indonesia juga membuka kesempatan kepada investor asing untuk menanamkan modalnya di Indonesia dengan cara turut serta 
70 | Ahmad Baidawi, A Zakarsi. Pemasaran Politik...

dalam transaksi jual beli saham yang dilakukan oleh pemerintah Indonesia. Dari sebagian saham yang dimiliki oleh investor asing maka pertumbuhan industri akan semakin cepat. Dalam pendapatan negara, dividen yang diterima oleh investor asing akan dikenakan pajak sesuai dengan ketentuan sebagaimana mestinya. Peranan lain dari investasi asing adalah sebagai berikut:

1. Sumber dana modal asing dapat dimanfaatkan untuk mempercepat investasi dan pertumbuhan ekonomi.

2. Modal asing dapat berperan penting dalam penggunaan dana untuk perbaikan struktural agar menjadi lebih baik lagi.

3. Membantu dalam proses industrilialisasi yang sedang dilaksanakan.

4. Membantu dalam penyerapan tenaga kerja lebih banyak sehingga mampu mengurangi pengangguran.

5. Mampu meningkatkan kesejahteraan pada masyarakat.

6. Menjadi acuan agar ekonomi Indonesia semakin lebih baik lagi dari sebelumnya.

7. Menambah cadangan devisa negara dengan pajak yang diberikan oleh penanam modal.

Secara garis besar, penanaman modal asing terhadap pembangunan bagi negara sedang berkembang dapat diperinci menjadi lima. Pertama, Sumber dana eksternal (modal asing) dapat dimanfaatkan oleh negara sedang berkembang sebagai dasar untuk mempercepat investasi dan pertumbuhan ekonomi. Kedua, Pertumbuhan ekonomi yang meningkat perlu diikuti dengan perpindahan struktur produksi dan perdagangan. Ketiga, Modal asing dapat berperan penting dalam memobilisasi dana maupun transformasi struktural. Keempat, Kebutuhan akan modal asing menjadi menurun segera setelah perubahan struktural benar-benar terjadi meskipun modal asing di masa selanjutnya lebih produktif. Kelima, Untuk negaranegara sedang berkembang yang tidak mampu membangun industri-industri berat dan industri strategis, adanya modal asing akan sangat membantu untuk dapat mendirikan pabrik-pabik baja, alat-alat mesin, pabrik elektronik, industri kimia dasar dan sebagainya.

\section{Kesimpulan dan Saran}


Pemasaran Politik Luar Negeri oleh Presiden Jokowi adalah bagian dari Diplomasi Preisden Jokowi untuk mengajak para Investor Asing untuk berinvestasi di Indonesia. Adapun strategi yang dijalankan oleh Presiden Jokowi dalam Pemasaran politik luar negeri sebagai berikut: Pertama, Menjalankan Politik Luar Negeri Bebas Aktif, Kedua, Melalui Diplomasi Ekonomi. Ketiga, Memberikan Kepastian Hukum Kepada Para Investor Asing yang berinvestasi di Indonesia.

Sebagai Saran untuk Pemerintahan Jokowi kedepannya agar sukses dalam Memasarkan politik luar negeri untuk menarik Investor Asing sebagai berikut: Pertama, Hendaknya semua persoalan yang ada dalam negeri diselesaikan secepatnya seperti persoalan konflik komunal, persolan HAM, dan Sosial budaya. Kedua, Persoalan Keamanan, hendaknya keamanan di Indonesia lebih ditingkatkan lagi agar jaminan keselamatan dan kenyamanan bagi para Investor Asing bisa terjamin. Ketiga, Kemudahan dalam Perizinan, hendaknya prosedur dalam perizinan investasi di Indonesia dipermudahkan lagi dan dipercepat.

\section{DAFTAR PUSTAKA}

\section{Buku}

Adam, Watson, 1984. The Dialogues between States, London, Methuem.

Coplin, William D, 1992. Pengantar Politik Internasional: Suatu Telaah Teorities, CV.sinar baru: Bandung

Firmanzah, 2007. Marketing Politik Antara Pemahaman dan Realitas, Jakarta: Yayasan Obor Indonesia.

Hatta, Mohammad, 1953. Dasar Politik Luar Negeri Republik Indonessia. Jakarta: Tintamas.

Hara, Abubakar. 2010. "Pengantar Analisis Politik Luar Negeri (Dari Realisme sampai Konstruktivisme)". Bandung: Nuansa.

Mas'oed, Mohtar, 1994. Ekonomi Politik Internasional dan Pembangunan, Pustaka Pelajar: Yogyakarta.

Nursal, Adman., 2004. Political Marketing: Strategi Memenangkan Pemilihan umum, Jakarta: Gramedia Pustaka Utama. 
72 | Ahmad Baidawi, A Zakarsi. Pemasaran Politik...

Newman, Bruce I., \& Richard Perloff, 2004. Handbook Of Political

Communication Research, United States Of America: Lawrence Erlbaum Associates.

S. L, Roy, 1995, Diplomasi, PT Raja Grafindo persada: Jakarta Utara

Winarno, Budi, 2002. Teori dan Proses Kebijakan Publik. Media Pressindo: yogyakarta.

\section{Jurnal}

Alami, Atiqah Nur, 2008. "Landasan dan Prinsip Politik Luar Negeri Indonesia", dalam Genewati Wuryandari (ed). Politik Luar Negeri Indonesia di Tengah Pusaran Politik Domestik, Jakarta: P2P LIPI dan Pustaka Pelajar.

Jufrida,Firdaus,dkk.2016. Analisis Pengaruh Investasi Asing Langsung (FDI) dan Invetasi Dalam Negeri Terhadap Pertumbuhan Ekonomi Indonesia. Jurnal Perspektif Ekonomi Darussalam: Universitas Syiah Kuala. Volume 2 Nomor 1. Maret 2016.

Jati. W. H. (2013). Memahami Globalisasi Sebagai Evolusi Kapitalisme". Jurnal Global dan Strategis Th. 7, No. 2. 2013.

RPJMN (Rancangan Pembangunan Jangka Menengah Nasional) 2014-2019. Di unduh pada bappenas.go.id. hal 13.

Tulus Tambunan, Daya Saing Indonesia Dalam Menarik Investasi Asing, (dipaparkan pada seminar Bank Indonesia, 2007)

Yuniarti, Peran Negara dalam Industrialisasi di Malaysia dan Singapura 19702000, tesis S2 (Yogyakarta: Program Pasca Sarjana FISIPOL HI UGM, 2007), hal. 130.

Kementerian Luar Negeri, Laporan Kinerja Kementerian Luar Negeri, Tahun 2015. Laporan Kinerja Kementerian Luar Negeri Tahun 2016. , Laporan Kinerja Kementerian Luar Negeri Tahun 2017.

\section{Peraturan Perundang-Undangan}

Undang-Undang Dasar Republik Indonesia No.22 Tahun 1999. 
Undang-Undang Dasar Republik Indonesia No 25 tahun 1999.

Undang-Undang Dasar Republik Indonesia No. 25 Tahun 2007

\section{Internet}

Laksono Hari Wiwoho, Kompas "Harapan dipundak Diplomasi", Lihat dalam:

https://nasional.kompas.com/read/2014/11/17/20080381/Harapan.di.Pundak .Diplomasi?page=all diakses pada 12 April 2019

Kompas, dalam Kolom Hubungan Luar Negeri, "Diplomasi Blak-blakan ala Jokowi", 17-11-14.

Visi misi Jokowi-JK..2014."Jalan Perubahan Untuk Indonesia yang Berdaulat, Mandiri dan Berkepribadian" diunduh pada:

http://kpu.go.id/koleksigambar/VISI_MISI_Jokowi-JK.pdf. hal 6-7. 